\title{
Selection Of A Currency Regime For Palestine
}

Vaughn S. Armstrong, (E-mail: armstrva@uvsc.edu), Utah Valley State College Cody G. Boyd, (E-mail: cgboyd2@uiuc.edu), University of Illinois

Norman D. Gardner, (E-mail: gardneno@uvsc.edu), Utah Valley State College

\begin{abstract}
This case deals with currency regimes, currency value and exchange rate management. It is presented in the context of a hypothetical decision regarding the currency for a future Palestinian state.
\end{abstract}

\section{CASE DESCRIPTION}

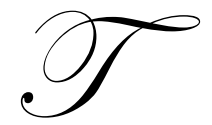

his case deals with currency regimes, that is, a country's arrangements regarding the currency to be used in the country. The objective is to introduce students to the different currency regimes that are possible and to the advantages and disadvantages of each and the mechanisms used to regulate currency value, as well as to provide them with additional experience researching international topics on the internet, especially information available through the International Monetary Fund and the World Bank.

The case is appropriate for use in an international economics or international finance class. Some aspects, e.g., those that deal with managing currency value, may be of interest in a macroeconomics class. The case has a difficulty level of four (senior level). It may take from one or three class hours for discussion, depending on the students' background in international parity conditions, the role of a central bank in management of money supply and interest rates, and the macroeconomics of tax policy, industrial policy and trade, and the extent to which the instructor wishes to explore these areas as part of the discussion. Students will require five to eight hours of preparation time.

\section{CASE SYNOPSIS}

One decision a country must make is what type of currency regime it will adopt. That decision and the world's response to the stability or weakness of the country's currency can dramatically affect the country's economy and the lives of its citizens.

In the last several years, there has been considerable activity as countries have changed or adjusted their currency regimes. You are likely aware of some of those changes; e.g., the euro has replaced the national currencies of twelve European countries; Ecuador, El Salvador and East Timor have "dollarized" and now use U.S. currency rather than issuing their own; Argentina abandoned its currency board, adopting a floating currency regime. In 2005, China adjusted its U.S. dollar "peg" (the value at which it maintains the yuan) and Turkey revalued its lira (1 new Turkish lira $=1,000,000$ old Turkish lira), and earlier this year, Zimbabwe revalued its dollar. You may also be aware that the Gulf Cooperation Council countries (Bahrain, Kuwait, Oman, Qatar, Saudi Arabia, and the United Arab Emirates) plan to unify their currencies in 2010.

Most people have heard reference made to the "gold standard" and to floating exchange rates, but many are not familiar with the variety of exchange rate regimes which a country can choose to adopt, nor with the factors that affect the decision. (Most people probably are not aware that currently no country's currency is linked to gold).

This case presents those issues in the context of a hypothetical future independent state of Palestine. Should an independent Palestinian state actually be formed as appears increasingly likely, the question of an appropriate 
currency regime must be addressed. This case requires you to evaluate the same question that policy makers governing Palestine will consider.

\section{INTRODUCTION}

Traditionally, a country's currency is one of the hallmarks of its statehood. When the Soviet Union dissolved, the nations that emerged acted quickly to create their own currencies. (A list of currencies for these and other countries appears online at: en.wikipedia.org/wiki/List_of_currencies. Facsimiles of many current and past currencies are available at: www.banknotes.com/images.htm and www.banknoteworld.com/). The creation of a separate currency may be a tactical move in a struggle for independence. Today, regions such as the Somaliland and Transdniestria, which have declared their independence, but are not generally recognized as separate countries, have their own currencies. (See, generally, en.wikipedia.org/wiki/Unrecognised_state.)

Despite some unresolved obstacles, it appears that in the relatively near future, a separate state, comprised of at least portions of Gaza and the West Bank, will be recognized in Palestine. A history of the proposals to create a Palestinian state and a discussion of some of the difficulties that remain appears at: en.wikipedia.org/wiki/Proposals for_a Palestinian_state).

It is not however necessary to wait until statehood is achieved to begin planning for a Palestinian currency or to consider whether Palestine should adopt some other country's currency as its money or pursue a monetary union with other nations. If Palestinian authorities decide to issue a separate national currency, they must also decide what approach to take to manage the currency's value. The management approach selected will not only affect the currency's value, but may also influence Palestine's trade and foreign investment in the country. The policy adopted regarding a country's currency is referred to as the currency regime or exchange rate regime. Currency regimes reported by the international monetary fund include: fixed peg arrangements, pegged exchange rate within horizontal bands, crawling pegs, crawling bands, managed float, independent float, currency board arrangements, and exchange arrangements with no separate legal tender, which includes currency union and currency substitution (use of another country's currency as legal tender - sometimes referred to as "dollarization"). A discussion of the different regimes and a list of International Monetary Fund member countries following each appears at: www.imf.org/external/np/mfd/er/2005/eng/1205.htm.

\section{PALESTINE'S ECONOMY}

Decisions made regarding a Palestinian currency have the potential to markedly affect the state's economy. The West Bank and Gaza strip, with a population of over 3.4 million people, face significant economic challenges. Unemployment and poverty rates are among the highest in the world, as is the population growth rate. Per capita GDP is among the lowest in the world. The area is highly dependent on aid and on funds donated by external organizations. Table 1 presents some descriptive statistics for the West Bank and Gaza. Additional descriptive data is available from the Palestinian Central Bureau of Statistics (www.pcbs.gov.ps) and from the World Bank (web.worldbank.org/WBSITE/EXTERNAL/COUNTRIES/MENAEXT/WESTBANKGAZAEXTN/0,,menuPK:2943 70 pagePK:141159 piPK:141110 theSitePK:294365,00.html).

Table 2 presents comparative statistics for several mid-eastern countries. This comparison provides context for some of the region's economic challenges, but also suggests that it is possible for a country like Palestine to improve its economic performance. Similarly situated countries are able to achieve much better results than Palestine presently does. That success is not necessarily dependent on oil reserves. Of the countries shown in Table 2, only Saudi Arabia and Turkey have reserves in excess of 50 billion barrels; Egypt and Syria have less than five billion barrels of reserves, while Israel, Jordan, and Lebanon have none. 


\section{PRIOR CURRENCY REGIMES IN PALESTINE}

The Palestine Authority governs portions of the West Bank and Gaza. The Palestinian Monetary Authority, established under the 1994 Protocol on Economic Relations and Annex V to the Israeli-Palestinian Interim Agreement on the West Bank and Gaza Strip (a copy of the former is available at www.thejerusalemfund.org/carryover/documents/economic.html and the latter at www.knesset.gov.il/process/docs/heskemb6_eng.htm), regulates Palestinian banks and may issue and regulate a national currency. To date, the PMA has not issued a separate Palestinian currency. Currently, transactions in the West Bank and Gaza are conducted in one of three currencies: the Israeli new shekel, the Jordanian Dinar and the U.S. dollar. Most bank accounts are maintained in U.S. dollars.

In the past, the area has often used another country's currency but on occasion Palestine has had a separate currency. From about the $13^{\text {th }}$ century until 1914, the Ottoman empire controlled Palestine and its currency was legal tender there. Between 1914 and 1917, the French Lira was the commonly used currency. In 1917, the area was placed under British mandate and Egyptian currency became the official currency, with both Ottoman currency and the British Pound also used in transactions. In 1927, a Palestinian Gold Pound, equal in value to the British pound, began to circulate and continued as the area's official currency until 1947. See, www.pnic.gov.ps/english/information/fact10.html.

\section{PALESTINE'S CURRENCY REGIME CHOICES}

A Palestinian state could elect to not issue a separate legal tender. It could continue the status quo, allowing the parties to a transaction to designate acceptable currencies. (Even if it selects this approach, it is likely to specify acceptable currencies for maintaining required accounts and discharging public obligations, such as taxes.)

Another approach that would not require the country to issue its own currency is to adopt another country's currency as Palestine's official currency. Ecuador, El Salvador and East Timor have "dollarized" and use the U.S. dollar as their currency. Montenegro uses the euro as its official currency. See Berg and Borensztein (2000) for a discussion of dollarization.

An additional alternative to issuing its own currency is for Palestine to join with other countries in a "currency union". The euro is a currency union that replaces the national currencies of twelve Eurozone countries. The Gulf Cooperation Council countries (Bahrain, Kuwait, Oman, Qatar, Saudi Arabia and the United Arab Emirates) plan to replace their currencies with a common currency in 2010. See Abed, Erbas and Guerami (2003). Jadresic (2002) discusses the consequences of a currency union for the GCC countries. Fusano and Iqbal (2002) consider the circumstances where a currency union may be advantageous and discuss the process of implementing such an exchange rate regime.

Palestine may decide to issue a separate national currency. If it does so it must decide what approach to use in managing the currency's value. It could choose to let the currency float freely or manage it relative to some specified indicator but having no pre-determined change in value ("managed float"). Hakura (2005) discusses the institutional characteristics that are appropriate for a floating exchange rate regime in emerging market countries.

The currency could be "pegged" to another currency or to a basket of currencies. (Currency can be pegged instead to a commodity such as gold. The "gold standard" was widespread as an exchange rate regime at one time but does not presently exist anywhere in the world. See en.wikipedia.org/wiki/Gold_standard.)

If Palestine decides to maintain a value for its currency with reference to another currency, that relationship might be formalized by adoption of a currency board, committing the country or its central bank to exchange domestic currency for the reserve currency or asset. For additional information about currency boards, see Hanke and Schuler (1994). 
In the absence of a currency board, the "peg" to another currency may be fixed, may adjust systematically (a "crawling peg"), may be allowed to vary within a specified range without intervention ("horizontal bands"), or adjust systematically within a specified range ("crawling bands").

\section{CURRENCY REGIMES IN SIMILAR COUNTRIES}

Countries near Palestine have several different exchange rate regimes. Table 3 identifies the currency arrangements used by nations within approximately 100 miles of Palestine. Table 4 presents the exchange rate arrangements for countries similar to the West Bank and Gaza in population (Panel A), in value of exports (Panel B) and in GDP and per capital GDP (Panels C and D). These tables indicate that there is no consensus either in the region or among similarly situated countries as to the optimal currency regime for countries similar to Palestine.

\section{RELATIONSHIP WITH ISRAEL}

Even after it secures complete independence, Palestine's proximity to and economic relationship with Israel may be an important consideration in the selection of a currency arrangement it selects. At present, the West Bank and Gaza have a measure of self government but remain parties to a customs union with Israel pursuant to the Paris protocol and its supplements. Many residents of the West Bank and some of Gaza are employed in Israel. This was true to a greater extent prior to the closures Israel instituted after commencement of the al-Aqsa intifada than at present. In addition, the bulk of Palestine's current trade is with Israel. Table 5 presents data on imports and exports between the West Bank and Gaza and its principle trading partners. (It should be noted that Israel is a transit state for many exports to and imports from other trading partners. This is due in part to the customs union and accommodates Israel's security concerns, but also arises from the limited development of Palestinian transportation facilities. As a result, the table may not accurately reflect the final destination for exports or source or imports.)

\section{THEORIES OF CURRENCY VALUE}

There are three principle theories of currency value: the flow theory, the stock theory and the asset theory. These theories differ in their assumptions regarding the institutional features and economic factors that affect currency value.

\section{Flow Theory}

The flow theory is essentially based on trade. This theory developed when the principle reason for currency exchange was for the purpose of maintaining trade between countries. International investment was relatively unimportant either because financial markets were undeveloped, or where they were developed, regulatory restrictions prevented foreign investors from entering the market. Under the flow theory, demand for a currency arises from demand for products produced in the country where that currency is used. (Purchasers of goods and service produced in a county must first purchase the country's currency.). Supply of a currency arises when residents of the country using that currency desire to purchase products produced in a foreign country. Exchange rates are determined by this supply and demand.

Under the flow theory, cumulative past trade deficits and surpluses also affect supply and demand and therefore exchange rates. E.g., if a country has experienced a trade surplus in the past, it already has a reserve of foreign currency reducing its demand for that currency for future transactions.

\section{Stock Theory}

The stock theory is grounded in money supply. The theory is sometimes oversimplified by stating that the change in value of a currency depends on the growth of the country's money supply relative to that of another country. That is, if the money supply of one country expands faster than the money supply of another or if one country's inflation rate is greater than that of another, its currency becomes correspondingly less valuable than that of the other. 
It is more correct to consider relative inflation (or change in money supply relative to growth in the economy). If two countries' money supplies grow at different rates but each grows at the same rate as the country's economy, the change in money supply would be non-inflationary and the exchange rates between the two countries would be stable.

The theory explicitly considers the effect of actual changes in relative money supply. It is less clear under the theory whether exchange rates incorporate expectations regarding future money supply changes.

\section{Asset Theory}

This theory posits that a currency is a financial asset. Currency value is determined by supply and demand, which are, in turn, affected by expectations regarding future value or the currency, and of products and investments from that country, as well as by current consumption. Consequently under the asset theory, value depends on supply and demand for current consumption and investment requiring the use of the currency and on expectations regarding future consumption and investment using that currency as well as risk associated with the currency.

\section{MECHANISMS USED TO INFLUENCE CURRENCY VALUE}

A country can manage its currency value using direct methods as well as indirectly. One direct method to manage currency value is the adjustment of money supply. This can be done both by a central bank through intervention (described below) and by a government through its ability to regulate the issuance of currency.

A government can also maintain its currency's value directly by restricting and/or regulating the exchange of the currency - either the rates of exchange or exchange mechanisms (provided of course that it can prevent black market exchange of the currency at unofficial rates). Such regulation typically involves the regulation of institutions that provide currency exchange services, as well as the import and export of currencies. Indirect methods to influence currency value are available to both governments and to monetary authorities (such as central banks). A monetary authority indirectly affects currency value whenever it implements monetary policy. Increasing interest rates to slow an economic expansion or stave off inflation may make investments in that country's currency more desirable, increasing demand for the currency and therefore its value.

A variety of government actions indirectly affect the value of the country's currency. (It is important to note that a government may take action for public purposes unrelated to currency value and may not even consider the effect on currency value.) A government indirectly affects currency value through its fiscal policy (including the amount of government spending, the specific goods and services purchased, as well as the identity and location of suppliers and vendors used), tax policy (including the amount of revenue collected relative to spending and the specification of activities that bear the burden of taxes), industrial policy (selection of sectors of the economy to support, whether the support takes the form of rhetoric or resources, regulation of foreign participation in domestic business activity, and the specification of educational requirements for the population or allocation of resources to support education in a way that affects the human resources available in the economy), trade policy (reflected both in tariffs or the absence thereof, and in non-tariff regulation of trade), and regulation of financial markets.

\section{Intervention}

When a monetary authority takes action to directly increase or reduce the value of a currency, the action is referred to as "intervention". Intervention consists of increasing the supply of that currency with a value considered to be too high and simultaneously increasing the demand for the currency with a value thought to be too low. This can be done, e.g., by using reserves of the "too high"-valued currency to increase reserves of the "too low"-valued currency. Additional supply of the high valued currency is thereby injected into the economy while demand for the low-valued currency increases and a portion of it that currency is removed from the market and held instead as reserves. When this is done without regard to the effect on domestic money supply, the intervention is referred to as "unsterilized". A monetary authority can "sterilize" an intervention by using open market operations to insulate the 
domestic money supply from the actions taken to alter the balance of the international supply and demand for the currencies involved.

\section{CASE QUESTIONS}

1. Discuss the advantages and disadvantages of the following currency regimes for Palestine?
a. currency board,
b. fixed peg,
c. crawling peg,
d. horizontal bands,
e. crawling bands,
f. managed float,
g. float,
h. currency substitution,
i. currency union.

2. Based on your understanding of the currency regimes and the demographics and economic situation of Palestine, which currency regime would you recommend for a newly independent Palestinian state?

\section{REFERENCES}

1. Abed, G.T., S.N. Erbas \& B. Guerami (2003). The GCC Monetary Union: Some considerations for the exchange rate regime. IMF working paper, WP/03/66. Retrieved August 31, 2005, from http://www.imf.org/external/pubs/ft/wp/2003/wp0366.pdf.

2. Berg, A \& E. Borensztein (2000). Economic Issues No. 24 -- Full dollarization: The pros and cons. Washington, D.C.: International Monetary Fund. Retrieved August 25, 2005, from http://www.imf.org/external/pubs/ft/issues/issues24/index.htm.

3. Fusano, U. \& Z. Iqbal (2002). Common currency. Finance and Development, 39(4). Retrieved August 31, 2005 from http://www.imf.org/external/pubs/ft/fandd/2002/12/fasano.htm.

4. Hakura, D.S. (2005). Are emerging market countries learning to float? IMF Working paper WP/05/98. Retrieved August 31, 2005, from http://www.imf.org/external/pubs/ft/wp/2005/wp0598.pdf.

5. Hanke, S. \& K. Schuler (2000). Currency boards for developing countries: A handbook. San Francisco, CA: ICS Press. Retrieved August 31, 2005, from http://users.erols.com/kurrency/icegrev.htm.

6. Jadresic, E. (2002). On a common currency for the GCC countries. IMF Policy Discussion Paper, PDP/02/12. Retrieved August 31, 2005, from http://www.imf.org/external/pubs/ft/pdp/2002/pdp12.pdf.

Table 1. Descriptive Statistics For The West Bank And Gaza

\begin{tabular}{lccccc} 
& $\mathbf{1 9 9 9}$ & $\mathbf{2 0 0 0}$ & $\mathbf{2 0 0 1}$ & $\mathbf{2 0 0 2}$ & $\mathbf{2 0 0 3}$ \\
\hline Population (millions) & 2.9 & 4.3 & & 3.2 & 3.4 \\
GDP (\$) (billion) & 4.2 & & 3.4 & 3.6 \\
$\Delta$ in GDP per capita (\%) & 3.3 & -9.9 & -22.6 & \\
\% of GDP added by: & & & & \\
$\quad$ Agriculture & 8.9 & 7.7 & 6.3 & 6.2 \\
$\quad$ Industry & 27.1 & 27.1 & 13.3 & 12.0 \\
$\quad$ Service & 64 & 65.2 & 80.4 & 81.8 \\
Exports (\$ of GDP) & $667(17.2)$ & $591(13.7)$ & $410(12.3)$ & $339(10.0)$ \\
Imports ( of GDP) & $2798(77.4)$ & $2837(72.7)$ & $1406(46.6)$ & $1506(49.0)$ \\
Aid per capita (\$) & 181.6 & & 500.3 & 288.6 \\
\hline Source: World Bank's World Development Indicators database, Development Economics central database and country unit staff.
\end{tabular}


Table 2. Comparison Of The West Bank And Gaza With Other Mideastern Countries.

\begin{tabular}{|c|c|c|c|c|c|c|c|}
\hline & $\begin{array}{c}\text { GDP } \\
\text { (million) }\end{array}$ & (Per capita) & $\begin{array}{c}\text { Unemploym } \\
\text { ent }(\%)\end{array}$ & Poverty & $\begin{array}{l}\text { Current } \\
\text { account } \\
\text { balance }\end{array}$ & $\begin{array}{c}\text { \% of GDP } \\
\text { (x 1000) }\end{array}$ & $\begin{array}{c}\text { Debt } \\
(\% \text { of GDP) }\end{array}$ \\
\hline $\begin{array}{l}\text { West Bank } \\
\text { and Gaza }\end{array}$ & 2300 & 725 & 27 to 50 & 67 & -1.295 & -57.1 & 108 \\
\hline Egypt & 316300 & 4200 & 10.9 & 16.7 & 2.113 & 0.7 & 103 \\
\hline Israel & 129000 & 20800 & 11 & 18 & 0.212 & 0.2 & 105 \\
\hline Jordan & 25500 & 4500 & 30 & 30 & 0.203 & 0.8 & 86 \\
\hline Lebanon & 18830 & 5000 & 18 & 28 & -2.389 & -12.7 & 178 \\
\hline Saudi Arabia & 310200 & 12000 & 25 & NA & 51.5 & 16.6 & 75 \\
\hline Syria & 60440 & 3400 & 20 & 20 & 1.1 & 1.8 & 32 \\
\hline Turkey & 508700 & 7400 & 9 & 20 & -15.3 & -3.0 & 74 \\
\hline
\end{tabular}

Source: CIA Data Book, dates vary - mostly 2003 and 2004, some data are estimated.

Table 3. Exchange Rate Arrangements For Countries Near The West Bank And Gaza

\begin{tabular}{lll}
\multicolumn{1}{c}{ Country } & \multicolumn{1}{c}{ Currency } & \multicolumn{1}{c}{ Exchange Arrangement } \\
\hline Egypt & Egyptian Pound & Managed float \\
Iraq & Iraqi New Dinar & Fixed pegged (U.S.\$) \\
Israel & New Israeli Shekel & Crawling peg (in principle) but bands are so wide $( \pm 22 \%)$, it effectively floats \\
Jordan & Jordanian Dinar & Fixed peg (U.S.\$, actual relationship may differ) \\
Lebanon & Lebanese Livres & Fixed peg (by law, but actual relationship differs) \\
Saudi Arabia & Arabian Riyal & Fixed peg, planned currency unification with GCC \\
Syria & Syrian Pound & Fixed peg, but regime differs in different markets \\
Turkey* & Turkish New Lira & Independently floating; maintained through monetary aggregate targets \\
\hline
\end{tabular}

*In 2005, Turkey revalued its currency. One of its "new lira" is worth 1,000,000 of the old lira.

Source: International Monetary Fund

Table 4. Exchange Rate Arrangements In Countries Similar To Gaza And The West Bank

Panel A. Similar population, 3.4 million

\begin{tabular}{lcl}
\hline \multicolumn{1}{c}{ Country } & Population (millions) & \multicolumn{1}{c}{ Exchange rate arrangement } \\
\hline Lithuania & 3.6 & Currency board (euro) \\
Albania & 3.6 & Float \\
Liberia & 3.5 & Float (extensive informal dollarization) \\
Uruguay & 3.4 & Float \\
Mauritania & 3.1 & Managed float \\
Panama & 3 & Currency substitution (U.S.\$) \\
Republic of Congo & 3 & Currency union (Central African CFA franc) \\
Oman & 3 & Fixed peg (U.S.\$) \\
\hline Panel B. Similar exports, 205 billion & & \\
\hline & Exports (billions) & \\
French Polynesia & 244 & Currency union (CFP franc) \\
Reunion & 214 & Currency union (euro) \\
Barbados & 206 & Fixed peg (U.S.\$) \\
Central African Republic & 172 & Currency union (Central African CFA franc) \\
Turks and Caicos & 172 & Currency substitution (U.S.\$) \\
Djibouti & 155 & Currency board (U.S.\$) \\
\hline Panel C. Similar GDP, $\mathbf{\$ 2 . 5}$ billion & & \\
\hline & & \\
Guyana & GDP (billions) & Managed float \\
The Gambia & 2.9 & Managed float \\
Guernsey & 2.8 & Fixed peg (British $£)$ \\
British Virgin Islands & 2.6 & Currency substitution (U.S.\$) \\
Netherlands Antilles & 2.5 & Fixed peg (U.S.\$) \\
Bermuda & 2.5 & Fixed peg (U.S.\$) \\
Republic of Congo & 2.5 & Currency union (Central African CFA franc) \\
\hline Panel D. Similar per capita GDP, \$600-\$800 & 2.1 & \\
\hline \$800 & & \\
\hline & & \\
\hline
\end{tabular}




\begin{tabular}{ll}
\hline Afghanistan & Managed float \\
Republic of Congo & Currency union (Central African CFA franc) \\
Kiribati & Currency substitution (Australian \$) \\
Ethiopia & Managed float \\
Madagascar & Float \\
Yemen & Float \\
\hline$\$ \mathbf{7 0 0}$ & Float \\
\hline Democratic Republic of Congo & Currency union (West African CFA franc) \\
Guinea-Bissau & Float \\
Tanzania & Fixed peg (euro) \\
Comoros & \\
\hline \$600 & Managed float \\
\hline Burundi & Float \\
Somalia & Float \\
Sierra Leone & Float \\
Malawi & \\
\hline
\end{tabular}

Source: CIA Data book and International Monetary Fund

Table 5. Trade Partners Of The West Bank And Gaza

\begin{tabular}{lcccccc} 
& \multicolumn{3}{c}{ Exports to } & \multicolumn{3}{c}{ Imports from } \\
& $\mathbf{2 0 0 0}$ & $\mathbf{2 0 0 1}$ & $\mathbf{2 0 0 2}$ & $\mathbf{2 0 0 0}$ & $\mathbf{2 0 0 1}$ & $\mathbf{2 0 0 2}$ \\
\hline Total & 400857 & 290349 & 240867 & 2382807 & 2033647 & 1515608 \\
Israel & 370000 & 273000 & 216000 & 1739000 & 1352000 & 1117000 \\
Arab countries & 29122 & 14576 & 15093 & 39668 & 36781 & 31074 \\
European Union & 1675 & 2453 & 8921 & 263605 & 358829 & 16116 \\
Americas & 71 & 128 & 203 & 66966 & 52242 & 8186 \\
\hline
\end{tabular}

Source: Palestinian Central Bureau of Statistics

\section{INSTRUCTORS' NOTE}

\section{Recommendations For Teaching Approach}

Students should read the case and the IMF's description of exchange rate arrangements. They should look over the IMF list indicating which countries have adopted the various currency regimes, and review some of the IMF working papers and other sources referenced in the case. (They should be encouraged to review the papers to gain a general familiarity with factors that affect the exchange rate regime decision and the advantages and disadvantages associated with the different regimes and to augment their understanding.) To the extent they are not already familiar with the demographic, political and economic situation in Palestine, they should be encouraged to review Palestinian Authority and World Bank documents and find additional sources of information regarding these factors.

Once they have done the background work, students should work in teams (during or before the class where the case is discussed) to consider the benefits and problems associated with each regime. They should then recommend (as a team) a currency regime and be prepared to explain their rationale for that proposal. Once the teams have made their recommendations, the decision should be discussed with the entire class.

\section{Discussion Of Case Questions}

1. Discuss the advantages and disadvantages of the following currency regimes for Palestine?
a. currency board,
b. fixed peg,
c. crawling peg,
d. horizontal bands,
e. crawling bands,
f. managed float, 


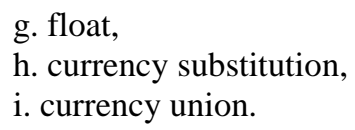

\section{a. Currency Board}

A currency board is a monetary authority that holds another currency as its reserve currency. (The currency board could use a commodity as its reserve, but none currently exists that does so.) It stands prepared to exchange its currency at a fixed rate and on demand for the reserve currency. Reserves may be maintained in the foreign currency or in notes denominated in that currency. The amount of reserves held is at least equal to the face value of currency issued. Reserves may exceed the outstanding liabilities (105-110\% percent) to provide "elbow room" in the event notes held in reserve do not perform as expected.

At one time, gold was held as a reserve commodity. Currently, the U.S. dollar, the euro, and the British Pound are the most frequently used reserve currencies. The general qualities that affect the choice of a reserve currency are stability and international acceptance.

Profits for currency boards typically average $1 \%$ of the domestic GDP. These come from interest received on notes held in the reserve currency and the revenue net of cost of producing the currency. An additional benefit of a currency board (relative to currency substitution or a common currency) is the nationalistic sentiment in holding the country's own currency.

Interest rates for countries employing currency boards tend to be similar to those of the reserve currency. Use of a currency board also eliminates the central bank's role as a lender of last resort. This does not indicate that bank failures are high in currency board countries. (In fact, in modern examples of currency boards, bank failures almost never occur.)

Currency boards provide an automatic mechanism to encourage discipline by the monetary authority. Should the monetary authority issue more currency than reserves, investors provide immediate discipline, exchanging for the reserve currency and immediately reducing the money supply. If there is doubt about the commitment to the currency board, the consequent short selling of the currency make it increasingly difficult to maintain the board. A response of this type induced Argentina to abandon its currency board in 2002.

Currency boards have no power to influence the economy by, e.g., manipulating the money supply to manage inflation. This is an advantage for countries whose currency would not otherwise have credibility (e.g., after the country was not disciplined with respect to a prior currency resulting in hyperinflation, or because a newly independent country has no track record to which the world financial community may look). A currency board provides an automatic check on government incentives to print money. But the government's inability to use monetary policy to stimulate the economy or correct inflationary pressures can be a problem, particularly if the country's economy is not correlated with the economy of the country's whose currency is selected as the reserve. This occurred in Argentina as the strong U.S. dollar caused Argentine pesos to be similarly strong with negative effects on Argentina's foreign trade. In a currency board country, the government remains free to use fiscal policy, industrial policy, trade regulation and other mechanisms to manage economic performance.

b. Fixed Peg.

Pegging a currency to another currency requires that the country specify the exchange rate it intends to maintain relative to the reference (or anchor) currency or basket of currencies, and depreciations. A country benefits from a fixed peg as a result of stability of prices when dealing with the anchor. It enhances foreign investor confidence in a currency, provided the government is viewed as sufficiently disciplined and the economy sufficiently strong to maintain the currency at the pegged value.

A currency peg is similar to a currency board in that it specifies an exchange rate. It differs in that there is no explicit obligation to actually exchange currencies at the specified rate. A country maintaining a peg experiences the 
same economic cycles as the anchor currency country. To the extent economies of the two countries are not synchronized, this can create economic problems for the pegged currency country. When there is doubt whether the country can maintain the peg, the currency is subject to attack by speculators who will short the currency hoping to profit when it declines in value. A brief discussion of the peg of the East Caribbean dollar to the U.S. dollar appears at http://www.eccb-centralbank.org/Public_Awareness/particles_7.asp.

\section{c. Crawling Peg}

A crawling peg occurs when a government specifies an exchange rate relative to an anchor currency but allows for systematic adjustments of that rate over time to avoid major unplanned devaluations or revaluations. This may enhance the stability of the country's economy and allow for continued growth to take place over time. In this system, the government exercises more control over the exchange rate and may adjust currency value to counter problems in the country's economy or that of the anchor currency.

Some of the benefits of a crawling peg are increased confidence in the currency's value as investors, producers, and consumers find the currency more predictable. This promotes stability in the market and can assist the country in developing its economy. Options associated with a crawling peg include amount and frequency of the regular adjustments in value.

\section{d. Horizontal Bands}

"Horizontal bands" refers to a pegged currency regime where the exchange rate for the anchor currency is allowed to fluctuate more than $1 \%$, but less that the amount of the band. There is a limited amount of monetary policy discretion, but the market will expect the monetary authority to intervene if the exchange rate moves outside the specified range.

\section{e. Crawling Bands}

Crawling Bands are a combination of a crawling peg with horizontal bands. The exchange rate for the reference currency adjusts systematically from the specified peg. Limited volatility around the pegged rate is permitted but the monetary authority will intervene if the is exchange rate moves outside the specified band.

\section{f. Managed Float}

In a managed float regime, the currency value is not set relative to another currency. It is free to fluctuate in value but is also subject to intervention by the monetary authority, which will endeavor to maintain value based on stated, or unstated, principles.

\section{g. Free Float}

A free floating currency's value is determined strictly by supply and demand in the foreign exchange market. Is simplifies the monetary authority's responsibility as it does not need to attempt to manage the currency or to intervene at any specific time. It can spend its effort worrying about other aspects of the economy. Problems with a free-floating currency arise from the volatility of the exchange rate. People who need to buy the currency must continuously reassess its value and hence the value of goods and services purchased or sold in that currency.

\section{h. Currency Substitution (e.g., "dollarizing”)}

In currency substitution, a country does not issue its own currency but specifies that another country's currency is legal tender for transactions in the country. Financially, this is equivalent to a currency board or a fixed peg, without the risk of attack that attends those regimes. 
Some reasons for adoption of a currency rather than creation of a new currency include the fact that transactions already generally occur in the other currency in preference to the official currency (perhaps due to lack of confidence in the official tender), price stability associated with the currency used, and that it eliminates the need to establish a monetary authority with attendant costs. Trade opportunities may improve due to convertibility of the currency adopted. This may be particularly true with respect to other countries that also use the adopted currency.

Problems arising from adopting a currency are similar to those associated with the economic effects of a currency board or fixed peg. The country would also sacrifice any "seniorage" that a country could earn by issuing its own currency.

It should be noted that the U.S. dollar may not be the appropriate currency to substitute. Palestine may be better advised to "euroize", "shekelize" or "dinarize".

\section{i. Currency Union}

Under a currency union, multiple countries agree to issue a common currency that was not previously the currency of another country. It has several appealing aspects, many of which are related to trade. Countries participating in a new currency union can expect their trade with each other to increase. This occurs because the parties to that trade can now avoid transactions costs of exchanging currency and need not take steps to manage risk arising from volatility of currency value.

\section{THEORIES OF CURRENCY VALUE}

Each of the theories of currency value has aspects that make it applicable to the situation of Palestine. While the flow theory might initially be viewed as inappropriate because it considers only trade, it may still have relevance if financial markets are either non-existent, regulated to limit or discourage foreign participation, or if risks associated with financial investments deter foreign investors. In those situations, trade related factors may predominate in determining currency value.

The stock theory may be of particular interest because the government and monetary authority is untested with respect to managing currency value. In the past, currency crises have occurred when either the government or the central bank is unable or unwilling to manage the money supply to control inflation or to maintain a designated "pegged" value of the currency.

The asset value allows for wide heterogeneity in expectations about the future of Palestine. Differences in those expectations may lead students to recommend different exchange rate regimes.

2. Based on your understanding of the currency regimes and the demographics and economic situation of Palestine, which currency regime would you recommend for a newly independent Palestinian state?

There is no correct answer to this question. Students should consider social and political. as well as economic factors. The justification for the exchange rate regime selected should be well reasoned and reflect an understanding of the various regimes and of the situation in Palestine.

Students may locates one or more of several published works cthat onsider the question of an appropriate currency for Palestine. Adams et al. (2005), Beidas and Kandil (2005), Cobham (2003), and von Allman and Fisher (2001). They should be encouraged to consider the rationale provided in those analyses but to independently consider the issues as they make their recommendation, and not simply adopt an "expert's" analysis. These authors are not in agreement regarding the best course for Palestine. Adams et al. (2005) recommend that a Palestinian state continue the existing currency regime rather than issue its own currency. Von Allman and Fisher (2001) conclude that a currency board is the best approach. Cobham (2003) recommends that Palestine initially adopt a currency board (relative to the Israeli shekel), with a view to ultimately pegging the currency to the euro. Beidas and Kandil (2005) recommend a fixed peg using the U.S. dollar as a reference currency but eventually moving to a more flexible system. 


\section{ADDITIONAL TOPICS THAT MAY ARISE IN DISCUSSION OF THE CASE}

\section{Islamic Banking}

Since Palestine is predominately an Islamic country, questions may arise during the discussion of this case about the differences between Islamic banking and banking found in western countries and with which students will be familiar. While a discussion of the differences between Islamic and western banking may not be directly relevant to the main focus of this case, if questions arise, the following should be helpful.

While the payment or receipt of interest forms the cornerstone of modern conventional banking, the payment or receipt of interest is specifically prohibited under Islamic law. Therefore financial instruments and loans that deal with interest are also prohibited. This prohibition against paying or receiving interest forms the nucleus of Islamic banking and its financial instruments.

In Islamic banking the suppliers of funds (lenders), rather than charge a fixed interest rate, become an equity partner in the business venture, profiting on a percentage basis along with the other owners of the enterprise. Based on this notion, several financial instruments and arrangements have become standardized into what has come to be called Islamic banking.

This banking system, established in the 1970s, currently consists of a variety of financial instruments or products. These include mudarabah (trust financing), musharakah (equity financing), ijarah (lease financing), murabahah (trade financing), qard al-hassan (welfare loan), and istisna (progressive payments).

Islamic banking is emerging as a viable alternative to conventional interest-based banking and financing. According to the General Council for Islamic Banks and Financial Institutions, there are currently 275 institutions worldwide that follow Islamic banking and financing principles, collectively managing in excess of $\$ 200$ billion. These institutions are spread throughout 53 countries, including Europe and the United States. For example, Citibank, which started serving the Middle East in the seventies, has tailored its products and services to Muslims. Citi Islamic, which operates out of Bahrain, offers a full range of products to corporate and institutional clients, from North Africa to the Far East.

For a more complete introduction to Islamic banking, see Samad et al. (2005) and Maniam et al. (2000).

\section{BIBLIOGRAPHY FOR INSTRUCTORS' NOTE}

1. Adams, J.L., K. Fonkych, K Crane \& M Schoenbaum (2005). Economics. In The RAND Palestinian State Study Team, Building a Successful Palestinian State (pp 107-162). Santa Monica, CA: RAND Corporation. Retrieved August 31, 2005, from http://www.rand.org/pubs/monographs/2005/RAND_MG146.pdf.

2. Beidas, S. \& M. Kandil (2005). Setting the stage for a national currency in the West Bank and Gaza: the choice of exchange rate regime. IMF working paper, WP/05/70. Retrieved August 31, 2005, from http://www.imf.org/external/pubs/ft/wp/2005/wp0570.pdf.

3. Cobham, D. (2004). Alternative currency arrangements for a new Palestine state. In D. Cobham \& N. Kanafani (Eds.), The Economics of Palestine (pp. 38-59). Routledge. An earlier draft of the paper was retrieved August 31, 2005 from http://repec.org/mmfc04/13.pdf.

4. Maniam, B., Bexley, J.J \& James, J.F. (2000). Perception of the Islamic Financial System: Its Obstacles in Application, and Its Market. Academy of Accounting and Financial Studies Journal, 4(2), 22-36.

5. Samad, A., Gardner, N.D. \& Cook, B.J. (2005). Islamic Banking and Finance In Theory and Practice: The Experience of Malaysia and Bahrain. American Journal of Islamic Social Sciences, 22(2), 69-86.

6. von Allmen, U.E. \& F. Fisher (2001). The choice of a future exchange rate regime in the West Bank and Gaza, in R.A. Valdivieso, U.E. von Allmen, G.J. Dannister, H.R. Davoodi, F. Fisher, E Jenkner \& M. Said, West Bank and Gaza: Economic performance, prospects and policies: Achieving prosperity and confronting demographic challenges. Washington, D.C.: International Monetary Fund. An overview of this paper was retrieved August 31, 2005, from http://www.imf.org/external/pubs/nft/2001/west/index.htm\#overview. 